\title{
Nothing but Trouble: Studies on the Effects of Reforms in Elderly Care in Sweden and Poland
}

Iwona Sobis

\begin{abstract}
Reforms of the public sector, conducted in the spirit of NPM since the 1990s, are frequently studied by Western and Eastern scholars. The research shows national variations in how the NPM idea was translated and adapted into a country's context and regulations. Care for the elderly is an interesting example of reforms conducted in the spirit of NPM, because it relates to welfare and health care and to the competences of provincial and local authorities in most European countries. This paper addresses the following questions: What do we know about the reforms conducted in the spirit of NPM and its practical implication within the field of care for the elderly during 1990-2010? What kind of knowledge about care for the elderly is still missing and should be developed in the future?

This paper conducts comparative research on what is known about the effects of the Swedish and the Polish reforms regarding care for the elderly. It argues that most literature points to negative effects, but also to the fact that there are still gaps in our knowledge about the effects of reforms concerning elderly care, especially regarding its organization. Hence, despite all the research done, we do not know what kind of social and health-care services for seniors represent the best practices for the future.
\end{abstract}

\section{Keywords}

NPM, public reforms, care for the elderly, welfare, aging Europe

1 Associate Professor, School of Public Administration, University of Gothenburg, Sweden. 


\section{Introduction}

Since the beginning of the 1990s, many scholars addressed aspects of NPM reforms (e.g. Pollitt and Bouckaert 2004; Drechsler 2005; Almqvist 2006; Nemec 2010; de Vries and Nemec 2012). Most researchers agree that NPM was a reaction to the increasing economic crisis in the world and globalization. Politicians perceived economic liberalization as a remedial measure to improve economic rationality. Nonetheless, NPM was interpreted differently (Pierre 1993; Gualmini 2007). It seemed impossible to follow any model without adjustments (Montin 1997; König 1997; Ferlie, Lynn and Pollitt 2005). At present some scholars proclaim NPM to be dead (Manning 2001; Pollitt and Bouckaert 2004), but the rudiments of NPM are still visible even if the concept is no longer used.

This article focuses on two EU member states: Sweden and Poland and their reforms in the field of care for the elderly. The countries became EU member in, respectively, 1995 and 2004. Sweden is known in the world for its generous and highly developed welfare state, whereas Poland is one of the post-communist countries. Sweden and Poland represent different levels of socio-economic development, but both countries have gone through the shift of their welfare paradigm at the same time. Also, both countries are relatively "young" members of the EU: Sweden has been a member for 17 years, Poland 8 years. It seems that the transformation of the welfare state in both countries has to some degree been the result of regulations and recommendations coming from the EU. The aim was to unite organizations, politicians and citizens to share the responsibility for the formation of society with regard to social needs. Going from a centrally planned to a free market system, the changes in Poland concerned the whole socio-economic and political system. In Sweden the transition went from a social-democratic to a more liberal system. In both countries decentralization and privatization of welfare services have been promoted under such slogans as "competition", "effectiveness and efficiency", "customer in focus", "free choice of care, insurance of education", "high-quality services" etc.

The reform of the care for the elderly, conducted in the spirit of NPM, became a controversial issue, criticized and attacked by e.g. the Swedish mass media, which "whistled loud" about badly working social and health-care services for the elderly. The headlines from the daily press speak for themselves: "Elderly Care with many Shortcomings" (Johansson 2009), "Home Visits Are Needed to Care for the Elderly" (Andree 2009), "Choice of Health Care is Under-Founded" (Starzman 2011), "CareChoice Provides Resources to those who Are Healthy" (Hansson and Larsson 2011).

Care for the elderly is an interesting case because in many European countries, it goes across boundaries between social and health-care services but also between the competences of provincial and municipal/local authorities. One can wonder why politicians continued the unsuccessful public reforms while not many have liked the idea. Did they not know about the negative consequences, or did they not 
care? It results in the research questions addressed in this paper: What do we know about the reforms conducted in the spirit of NPM and its practical implication within the field of care for the elderly during the period of 1990-2010? What kind of knowledge about care for the elderly is still missing and should be developed in the future?

It is argued that there are still gaps in our knowledge about care for the elderly, especially regarding its organization, both in the highly developed country and in the new democracies.

The paper is structured as follows: after the Introduction, a brief overview of NPM theory will be presented in section 2 . Section 3 focuses on the method. In section 4 , an overview of the actual national reforms in the field of care for the elderly in both countries is presented. In section 5, an overview of the Swedish and Polish studies will be presented regarding the practical implications of the public reforms conducted in the spirit of NPM on: (1) competitiveness on the market, (2) contract management and (3) decentralization and internal control from both countries. Finally in the conclusions, the research questions will be answered and conclusions drawn.

\section{New Public Management}

Two Americans - David Osborne and Ted Gaebler (1992), erstwhile advisors to Ronald Reagan - and one Englishman - researcher Christopher Hood (1991; 1995) - are perceived as the "spiritual fathers" of New Public Management (NPM). From the beginning NPM has been divided into two main movements; Osborne and Gaebler argue: "neither traditional liberalism nor traditional conservatism has much relevance to the problem our governments face today" (xviii). If the system is wrong, it must be changed because "civilized society cannot function effectively without effective government" (xviii). According to them, the delivery of public services should be left to the private sector. The state ought only to steer and regulate but nothing more (Osborne and Gaebler 1992, 1; Pollitt and Dan 2011, 2ff). In Europe, Hood $(1991,1995)$ emphasizes that the public sector should not be discarded of, but should be better organized and managed internally by creating internal quasi-markets. Both streams of NPM seem to be relevant to identify trends in the care for the elderly. The Swedish researcher Roland Almqvist (2006) argues that NPM is an ambiguous concept consisting of many ideas and many theories on how to administrate public organizations. According to him, it is a question about "the optimal leadership" anchored in the concept of Total Quality Management (TQM). The issue of quality is working like a leitmotif, going across three theoretical perspectives of NPM movement: (1) the theories focusing on competition on a market, (2) theories focusing on contract management, and (3) theories about decentralization and internal control (13-15). The first perspective has the capacity to explain, e.g., how competition works in practice, if competition improves effectiveness and 
efficiency, what kind of attitudes follow the introduction of competition, what happens with the quality of services if organizations start to compete on a market. The second perspective focuses on contract management and public procurement, on relations between purchaser and provider. In this model, politicians are purchasers who choose and buy services offered by various organizations producing services. Citizens become clients, who can choose only among the services politicians allow to sell them. This perspective can explain how contract management works in practice, how contracts influence the quality of care services, how the quality of services is measured, and if it is really a good idea to provide care services by means of contract management. The third perspective concerns decentralization and internal control. It helps to explain how the public sector and public services are organized after decentralization: if decentralization has a positive impact on staff's motivation, its qualifications, competence development, and recruitment; if management by objectives is working in practice; and how organizational performance can be measured.

\section{Methodology}

This paper proposes a comparative research on the practical implication of the public reforms conducted in the spirit of NPM within the field of care for the elderly in Sweden and Poland, judged with the benefit of hindsight twenty years after. For the Swedish case, I have used the journals, the databases GUNDA and LIBRIS from the Library of Gothenburg, the governmental official reports [SOU], and the reports from the Swedish Association of Local Authorities and Regions (SKL). Approximately 35 relevant scientific articles, bachelor and master theses, doctoral dissertations, official reports about the reforms of care for the elderly, published between 2000 and 2012, were analyzed. Regarding the Polish studies, from about 100 scientific positions published during the same time and dealing with care for the elderly, I selected only 15 publications to analyze. They are from the Institute of Labor and Social Studies (Instytut Pracy i Spraw Socjalnych), the official reports from Najwyższa Izba Kontroli - NIK (the Supreme Chamber of Control) and from various Polish libraries that were catalogued under the topic older age. It is a big disproportion regarding data collection; 35 articles from Sweden and only 15 articles from Poland. However, there are some explanations to this situation. When reading abstracts, conclusions or sometimes looking through the texts, I have noticed a big difference between the Polish and the Swedish articles in this research field. Firstly, the Polish researchers are still looking for pragmatic ideas how to organize care for the elderly with regards to their needs. Sometimes it was a question about the model of the welfare state, where care for the elderly constituted an integral part of it. Most Polish articles referred to and summarized the Western theories or models of welfare. The Western welfare models were perceived and discussed as remedial measures to solve domestic problems in this field. Secondly, in Poland there are 
eminent researchers, who have the opportunity to publish their articles in journals or books, while students' theses on the bachelor and master levels are rather invisible on webpages of Polish university libraries. Instead, it is quite easy to access doctoral dissertations on the Internet. Of course, this data imbalance could influence the result of the analysis. However, even the limited data from Poland could provide useful information about the general situation of the Polish care for seniors.

Roland Almqvist's (2006) distinction between perspectives of NPM, i.e. (1) Competition, (2) Management by contract, (3) Decentralization, structured the analysis of the Swedish and Polish studies. But because the quality of service delivery is also thought to be of utmost importance, this is seen as a fourth category. The most relevant concepts for each category, which have steered the selection of studies and the most dominant themes in each category, were identified to describe and enable a comparison between Sweden and Poland, to answer the research questions and draw conclusions. The next sections present the outcomes of this analysis.

\section{A short presentation of public reforms within the field of care for the elderly}

In this section the actual reforms, e.g. state regulations within the field of care for the elderly in both countries are presented. The share of older persons (65+) in the total population in the EU-27 grew from $13.7 \%$ in 1990 to $17.2 \%$ in 2009 , while the share of the youngest (0-14 year old) decreased from $19.5 \%$ in 1990 to $15.6 \%$ in 2009. In Sweden, a relative balance between the older persons $17.8 \%$ for 1990 and 2009 and the youngest (17.8\% for 1990 and $16.7 \%$ for 2009, respectively) can be observed. In Poland, the situation is more problematic. The share of the youngest (0-14 year old) decreased from $25.3 \%$ in 1990 to $15.3 \%$ in 2009, while the share of seniors increased from $10 \%$ in 1990 to $13.5 \%$ in 2009 (Eurostat 2011).

There is especially a problem because of the simultaneous decline of GDP, public revenues and stabilization expenditures, which influence the allocated resources for the care for the elderly in the EU-27. In 2008, the GDP per capita was $€ 31,300$ for Sweden and only $€ 8,100$ for Poland. For years, Sweden has been one of the most generous welfare states among the EU-27 countries. In 2008, the EU-27 spent total on social protection about $€ 5,832$ per capita, of which the share of care for the elderly was $0.41 \%$. Corresponding data for Sweden was $€ 8,705$ per capita on social protection, of which $2.33 \%$ were spent on care for the elderly. In Poland, the state's expenditure on social protection was $€ 1,278$ per capita, of which $0.22 \%$ went to the care for the elderly. It should be added that the purchasing power in Poland, as in other countries from Central and Eastern Europe (CEE) is still difficult to compare with the purchasing power within the EU's highly developed democracies. The Poles earn much less, but they also pay much less for housing, maintenance and different types of services. It seems that the expenditures on social protection 
and the care for the elderly in the country is in proportion to the Polish structure of earnings (Eurostat 2001, 235, 286).

How did both countries react to these demographic changes and the increasing costs of elderly care?

\section{a. Sweden}

Sweden has been well known for decades for its highly developed and well working welfare state. When the economic crisis was knocking on the door at the end of 1980 s, the Swedish left-wing government decided to join the EU. They implemented the economic-liberalization program in a Swedish way, although the reforms were in conflict with the Social Democrats' ideology (Pierre 1993; Hood 1991, 1995; Montin 1997). Regarding care for the elderly, older people was seen as "bed blockers". Thus, the idea appeared to integrate the efforts of the social and health-care sectors, as the politicians argued: "cost for care of a person in a specialized ward is higher than in a nursing home" (Andersson and Karlberg 2000, 2).

On 1 January 1992 the Edel-Reform [Ädelreform] was implemented, understood as a delegation of care for the elderly. The subsequent right-wing government assigned 5.5 billion SEK to a restructuring of social and health-care services. Some amendments during the years from 1992 to 2011 completed the Edel-Reform. The adjustments of the Welfare Act and the Health Care Act necessitated the social and medical sector to cooperate by creating a synergy effect when providing care for seniors. The Welfare Act of 1993:390 made municipalities/communes plan their activities, cooperate with county councils and other communal agencies. The Welfare Act of 1997:313 modernized the Welfare Act of 1980:620. According to $\$ 19$ and $\$ 20$, social-welfare committees ought to ensure such care conditions that older people can live independently, safely, and with respect for their autonomy and integrity. The elderly should first get support and assistance at home, and only in care facilities if absolutely necessary.

The Health Care Act of 1992:567 of 1 July 1992 modernized the Health Care Act of 1982:763 [FSF: Lag 1982:763]. According to \$24, municipalities/communes were obligated to employ a nurse with a special medical responsibility [MAS] for older people. Since this regulation, it was possible to talk about the Whole-ElderlyDelegation-Reform [Hel-Ädel]. Bed blockers were moved to open care for the elderly. The expectation was, among others, to shorten waiting queues for medical treatment for other patients. Some years later, the Government Bill of 1996/97:60 [Reg. proposition 1996/97:60] made palliative and long terminal care the first priority within the Swedish field of care for the elderly.

\section{b. Poland}

Since 1990, Poland has been in transition from socialism to a market economy a "shock therapy" aimed at rapid economic liberalization, but with the benefit of 
hindsight one can conclude that the country was creating capitalism without any capital. Three types of economic policy were introduced at the same time; (1) macroeconomic stabilization (S policy), (2) microeconomic liberalization (L policy), and (3) fundamental institutional restructuring (I policy). These reforms were interdependent. The first two aimed at market-oriented reforms, and the third addressed the institutional adaptation to a free market economy (Balcerowicz 1995, $318 \mathrm{ff} ; 1997,209 \mathrm{ff} ;$ Sobis 2002, 63ff). The major problem was the increasing unemployment, because many establishments and factories had to reduce the so-called "social employment" that was normal during socialist times.

In this revolutionary situation, the care for the elderly was not the major priority. Seniors' needs were left to their families. The regulations of care for the elderly were laid down in the general regulations of the Welfare Act of 29 November 1990 that was in force until 30 April 2004 (Dz.U. z 04-04-2004 r. Nr 64, poz. 593). This document obliged the family to take responsibility for their own elderly family members. According to Article 9, the responsibility for the execution of social-assistance tasks and duties rested on local government, its subordinated units and the state government. Municipality and district welfare offices could not refuse any assistance, even if other persons were obligated to give support to the seniors in their own families. The provision of care services for the elderly belonged to the municipality's tasks like providing shelter, food, necessary clothing for the deprived people, including the homeless, organizing and running local childcare centres, community centres, environmental clubs for children and organizing sheltered housing. This included specialist and residential/nursing assistance. It was the county council that supervised the welfare tasks assigned to local government by this Act. Moreover, county authorities were responsible for giving and taking back licenses or permits to conduct conditional communal welfare homes addressed to various groups in need. The Welfare Act also described the required competences of staff working with welfare tasks and duties. According to Article 12b, the ministry responsible for social protection was expected to develop the area of social assistance, manage commissioning and funding research in this field, organize opinion analysis of social assistance, decide standards for welfare tasks performed by organizational units, supervise their implementation and conduct analyses of the effectiveness of social assistance from recipients' perspectives or even analyse effectiveness of various types of benefits.

Thus, the Polish regulations did not differ that much from the regulations in Sweden or other EU countries. Most important was that the Welfare Act of 1990 (part III) regulated the organization of welfare in general. However, it did not have any special focus on care for the elderly.

In Article 23 of the Welfare Act of 12 March 2004 the Ministry of Social Protection is made responsible for promoting new methods to create a synergy effect when cooperating with non-governmental actors. Article 25 emphasized that gov- 
ernment authorities and local government can delegate welfare tasks by providing grants to finance them. Welfare tasks could be co-commissioned to: NGOs active in social welfare, legal persons like the Catholic Church, other churches, religious associations and business entities, if their status was perceived as an "eligible entity" to provide welfare services. According to Article 26, the public procurement had a decisive importance for the organization of welfare services. Participants in competition on a market should take into consideration the principle of subsidiary, effectiveness, fair competition and transparency for welfare services. Moreover, eligible entities might also apply for tasks that were previously carried out by other companies, as long as the new offer met the major priorities of welfare tasks and guaranteed the delivery of services in accordance with expected standards. Thus, in comparison to Sweden, the Polish regulations also created the foundation to decentralize and privatize welfare services by allowing public, NGOs, and private entrepreneurs to carry out welfare tasks and to participate in competition on a market.

Regarding the care for the elderly, Poland developed the continental variant of a welfare state based on the rudiments of Bismarck's social politics, in which family and family relations play a central role. However, after 1990, the Polish model of care for the elderly has been influenced by Western assistance, especially from Sweden, Germany, Denmark, Netherlands, but also from the USA, the United Kingdom, France and others.

\section{Effects of the reforms in Sweden and Poland}

\section{a. Competition on the care market}

\section{Sweden}

Christian Gerlach and Per Gunnar Edebalk (2005) studied the organization of care services for the elderly and their market orientation in Sweden and Germany. In Sweden, the mercantilization of care services is regulated by the Welfare Act of 2001:453, chapter 3, $\$ 1$ [SoL 2001:453, kap 3, \$1], which emphasizes the importance of high-quality services. The Municipal Welfare Board is obligated to create criteria for quality and ensure their application in practice, but the procedures to achieve "good" quality services is not uniform in the country because the quality criteria vary among municipalities. Since the implementation of public procurement, competition among care performers has always been connected to quality. The idea was that care users could choose among care providers, but the strict regulations in Sweden were the reason why they could only choose among those with whom politicians had signed a contract. The introduction of care insurance caused private companies providing care for seniors to consolidate themselves in a care-market to get a stronger position. 
There are a few studies about privatization. Ragnar Stolt and Patrik Jansson (2006) examined the practical consequences of the Edel-Reform. The introduction of public procurement, regulated by the state, led to ten medium-sized private companies providing care for the elderly appearing on the Swedish market in the late 1990s. In 2006, there were four concerns, Attendo Care AB, Carema Äldreomsorg $\mathrm{AB}$, Aleris Äldreomsorg and Förenade Care AB, which constituted ca. $14 \%$ of the total long-term care sector. The sector had an oligopoly structure, dominated by a small number of sellers. Characteristic were the lower costs, the ease of staff recruitment and their mobility, the short term of the contracts and the limited resources for those concerns. The consolidation of smaller care companies into concerns allowed the private contractors to take a stronger position on the market in comparison to the Swedish municipalities. The competition between public care services and the concerns seemed nonetheless artificial. During 1995-2006, the number of private actors decreased in general, but the care market was flourishing and attracted new investors as never before. Three years later Ragnar Stolt and Ulrika Winblad (2009) continued their studies about the privatization of the care for the elderly. They investigated the mechanisms behind the increase of private care services. According to them, only a few scholars studied "the growth of privatization in Sweden, and how the privatization was carried out" (903). The authors studied the variation of privatization in the Swedish municipalities and used a longitudinal database LOUISE - from the Statistics Central Office, which was adapted to the research by creating a unique set of regression coefficients for each year to make possible comparisons among municipalities. According to Stolt and Winblad, the Swedish care for the elderly was transformed from a homogenous public sector to a more diverse market, on which private entrepreneurs competed with other actors for the provision of care for the elderly. The number of private care providers increased from ca. $1 \%$ at the beginning of the 1990 s to $13 \%$ in 2003 . Also a large variation in the degree of privatization of care services among municipalities was observed. It is noteworthy that "right-wing municipalities tended to introduce private alternatives irrespective of the economic situation" (911). However, even left-wing municipalities introduced privatization, either because of their economic situation or because their neighbor also had a large share of private care services. Thus, the privatization of the elderly-care sector proved diffuse in which "economy, ideology and geographical proximity are factors intertwined in a complex relationship" (911).

Marianne Svensson and Per Gunnar Edebalk $(2006,6)$ studied two Swedish municipalities, Nacka and Solna, and their expressions to lock potentially users. According to the rules, all care providers received the same compensation for care services; thus, competition concerns in fact only quality. According to the authors, care providers always promise kind and respectful treatment of customers. They ensure that their staff has high competences and skills to build satisfactory relationships with care users or theirs family members. They ensure that care users can influence service provision, which always turns into something extra. Nonetheless, the tough 
competition can cause some care providers to choose to work in those municipalities where the pressure and controls are weaker. This study shows that care users and their family need information about care providers, about who they are, what additional services they can provide, and what free-time activities they can offer in nursing homes or home services.

Most Swedish studies referred to the Edel-Reform. Its new regulations envisaged a new role for municipalities. They were obligated to cooperate with other organizations, especially with private companies providing care services for the elderly. The organizational market environment and its pressure on municipalities proved important for the organization of care for the elderly. Looking at it from an institutional perspective, the institutions, e.g. state regulations, directives, guiding principles, values and norms for care providing, contract formation and mutual obligations, showed that the various stakeholders within the organizational environment also had different interest. The institutional setting legitimized the existence of many care providers on this market, enforced rules for cooperation and the kind of support a care provider could expect to get from other organizations or organizational units when developing its own activities.

Österström (2007) and Berggren (2010) studied the intra-organizational cooperation, i.e. the new power relations between the actors from the various units of the same organization involved in the care for the elderly. Both authors used Thompson's resource-dependence theory (1969) to show the organization's vulnerability and the dependence on resources from the organizational environment. This theory was expected to explain: (1) why organizations cooperate, (2) what strategies they use in their cooperation, but also (3) to explain different forms of cooperation. From these two studies it appeared that the boundaries of competences between the county council and the municipal authorities were often unclear when sharing activities and responsibilities. The division of competences by the state regulations created confusion, uncertainty and even a struggle for power between the organizations involved. In consequence the seniors did not receive high-quality care services. Österström (2007) was critical towards the allocation of resources for care provision by arguing that the organization of care services was presented only from the point of view of one organization/units involved in the cooperation, while in care provision there are many other actors from different units of the same organization present. Thus, intra-organizational cooperation proved a complex phenomenon requiring another methodological approach. Each organization or organizational unit follows its own objectives, rationality, and understanding for the norm of professionalism. It was shown that voluntary organizations interpreted them quite differently than private care companies.

Karin Edmark (2007) studied the strategic competition and money involved in childcare, school and care for the elderly in the Swedish municipalities. It proved that the municipal politicians seek electoral support and promise better access to 
social services and better information about the care services in local mass-media (9) than neighbouring municipalities offer. The research confirmed a correlation between the municipality's expenditure on care for the elderly and the neighbours' expenditures on care for the elderly. The study further showed that the increase of expenditures on care for the elderly in a neighbour municipality of about 1.00 SKR could cause the increase of expenditure on this purpose in a municipality about ca. 0.70 SKR. Hence the expenditures seem to be steered according to political strategy.

Thomas Wilhelmsson and Henrik Jordahl (2010) also examined the cost and quality of care services in Swedish municipalities and how the care services were affected by the private care providers that were financed publicly. They used a survey from 2009 based on 135,000 care users. $38 \%$ of the respondents who got care in special housing and ca. $75 \%$ from ordinary housing replied to the survey. A regression analysis based on 28 indicators of costs for all the Swedish municipalities indicated a negative correlation between the percentage of users of private care providers and its cost. The introduction of private agencies did not decrease the costs of care services for seniors. The measurement of care quality was divided into the subjective and the objective measures of quality. The subjective measured quality showed a negative correlation, while the objective one proved to be positive. The difference was explained by the use of a quality-shading hypothesis and incomplete contracts. According to the authors, clear goals for care services for the elderly and a clear definition of what is good quality have a decisive importance for the competition among private and public care providers (25ff).

\section{Poland}

The first Polish studies about competition on the market appeared after 2000. The Polish studies about the privatization of care services for the elderly were anchored in the general reform program of shock therapy. No one Polish scholar focused on competition among care providers in the early 1990s. According to the Annual Report of the Ministry for Labor and Social Policy, in 2005, 812 homes of social welfare were operational in Poland; 221 of which were addressed to seniors $(71 \%$ were intended only for them and $29 \%$ for people with typical illnesses for old age and those with other illnesses). This report proved to be incomplete. It took into account only the institutions financed from the municipal or/and counties' budget. The report omitted all nursing homes conducted by business and charitable organizations. Łukasz Jurek $(2007,18)$ made his own calculations. According to him, 211 welfare homes [DPS], i.e. $75 \%$, were run by local government, $22 \%$ by non-public organizations, and only $3 \%$ by business organizations. However, the report of NIK [the Supreme Chamber of Control] showed that the Polish governors did not have full knowledge about the number of operating nursing homes for the elderly in their area. Inspections conducted within 14 provinces showed that 222 commercial nursing homes for the elderly were acting without any operating license. In the Mazowiecki province alone 160 private institutions were detected, only 8 of 
which were registered (Jurek 2007, 20 after Informacja... 2006, 33). According to Mirosław Grewiński $(2006,14)$, research on the commercial sector, the social-economy sector and socially engaged business is underrepresented. In general, studies evaluating the effectiveness and efficiency of the mentioned sectors (public, NGOs and private) are lacking, probably because the issue proved to be brand new in Poland, but international comparative analysis of mixed systems is also lacking, even in highly developed countries like Sweden.

Józefina Hrynkiewicz (2002) argued that the partly transfer of state duties and tasks at the local level from public to non-public and private organizations resulted in increased effectiveness of social policy. However, economic calculations and empirical evidence to confirm this statement are lacking. Most studies just use theoretical reflections about welfare pluralism. When reading the Polish studies, it becomes clear the researchers are still looking for the optimal model of the welfare state for Poland. The issue of competitiveness is discussed indirectly, a little here or there, but not in a systematic way. Jolanta Supińska (2003) compared four sectors: informal, market, public and governmental. She concluded that each sector is functioning according to its own logic, and its own assumptions about the social welfare. According to her the mentioned sectors can and ought to cooperate together, because it is beneficial for the society. Thus the issue of the actual effects of competitiveness is marginalized in favor of a normative approach to what welfare should look like. The cooperation and the complementing efforts are perceived as a good solution regarding care for the elderly. Supińska asks whether there is the ability to combine the advantages and eliminate disadvantages of each sector in a conscious way. She concludes that if this is not the case the welfare mix may not produce good results.

According to Eukasz Jurek $(2007,18)$, the systemic solutions enable competition among various care providers on several levels, i.e. between different forms of care services (environmental, semi-open, and institutional), between different types of institutions (welfare homes [DPS], nursing homes, and family assistance homes), and between specific institutions carried out by different actors (public institutions, non-profit organizations and private business). Competition should lead to the liquidation of weaker institutions and to a rising standard for care services. The vast majority of changes should take place to the benefit of residents. Similarly to Supińska, Jurek takes a normative position and argues that competition among various care providers should be based on an equal treatment of all stakeholders, e.g. equal access to information and resources. He criticizes the current system, because entrepreneurs running welfare homes cannot act on behalf of local governments. They cannot use public funds even if they perform the same tasks. Nonetheless private care organizations have to meet the same standards of service quality as public institutions and NGOs. The reason why the commercial welfare houses are excluded from cooperation with local government is not clearly explained. 
Jurek takes a normative tone again and argues, just like Supińska, that local government should not see businesses and non-profit organizations as competitors but as potential public-private partnerships to serve a target group by working together for a common good (Jurek 2007, 20). Both authors advocate the model of plural welfare or mixed welfare.

As can be seen from the Polish and Swedish studies, the privatization emerged out of international pressure in Poland and in Sweden as a result of (right-wing) ideology at the municipal level, out of financial needs if the municipality was run by Social democrats. In Sweden the results diminished financial resources for the care institutions, while in Poland they brought about the emergence of a not-registered uncontrolled care sector.

The studies in Poland and Sweden reveal that the privatization did not proceed without problems. The lack of a level playing field between public and private care providers, the lack of coordination, the decreasing quality of care and the increasing instead of diminishing costs for care dominate the outcomes. These outcomes emerge, even though the research is often biased in favour of NPM-like reforms and giving a more prominent role to market actors.

\section{b. Contract management in the care services}

\section{Sweden}

According to the governmental report SOU 2001:79, contract management created new social inequalities; seniors with a higher level of education and higher incomes could choose the home services they needed on a market, while for the poor and less educated elderly, family was expected to provide care services. The Swedish Law of Family did not obligate adult children or relatives to take over caring responsibilities for their family seniors. Nevertheless, it appeared from the report of the National Welfare Board (2003) that four Swedish municipalities introduced such guidelines in 2002. Thus, the family involvement in care providing for their own elderly can become a pattern other municipalities might intend to follow in the near future.

Larsson and Shebehely $(2006,416)$ studied the competition between municipal and private care providers, and it proved a very delicate issue. According to state regulations, public procurement plays a central role for the Swedish care for the elderly; it concerns public and private care providers. The competition on this market is regulated firstly by the state and secondly by a contract between purchasers and providers. A contract's duration is limited: some month, some years, due to the needs and mutual satisfaction about cost and quality. One-third of the Swedish municipalities used this form of contract management (415). What proved to be the most exciting part of this research was a comparison of the kind of care the seniors in Sweden received about 15-20 years ago and how it is nowadays. The authors de- 
scribe the contents of home care tasks from the past in detail, i.e. what tasks had to be done with the granted hours by the care provider, e.g. cleaning every two weeks, a shower on Wednesdays etc. Care recipients and nursing staff could decide in a mutual agreement how the care hour would be used in practice. Currently, from the municipal policy documents and guiding principles about what tasks should be done with the granted hours by the care provider, the descriptions of care activities is given in minutes, it is standardized and a rather grim picture of geriatric care (418). Many older people with less extensive needs of care services are left outside the municipal obligation to provide any care services to them.

\section{Poland}

From the Polish studies it appears that the contract has become a very important instrument of de-monopolization of public institutions. It allows for transferring public functions (de-concentration) from the state to the lower administrative bodies. According to Rymsza (Grewiński 2006, 12 after Rymsza 2003, 261-277), contract management and public procurement were used by central public bodies and by public institutions at the local level. It has been observed that the non-governmental sector increases rapidly in Poland, which creates new opportunities for organizing public procurements for potential care providers and for securing in this way the quality of social services for the elderly. However, in Poland neither NIK [the Supreme Chamber of Control] (Informacja... 2010; 2011) nor the Department of Social Research at the Central Statistical Office of Poland (GUS 2010) have conducted any analyses of the resulting quality of the care provided. Even scholars from universities did not provide any knowledge about how the Polish contract management was working in practice or what practical implications on the quality of care services were observed after the implementation of the purchaser-provider model, or simply how relations between buyers and care producers worked in practice. Probably, the economic backwardness was responsible for the situation that not all the aspects of the social policy received the same attention and chance to make progress (Informacja... 2010; 2011).

The conclusion cannot be but grim. Quality does not seem to be an issue in care for the elderly, and comparing the care provided for nowadays with that given 20 years ago does not make one optimistic. Contracts fail the control of quality standards and pretend that measuring everything in minutes does the job well enough. A very serious aspect is the scarce and often lacking research by independent researchers on this topic.

\section{c. Decentralization in the care services}

\section{Sweden}

One effect of decentralization concerns the new relations between different governmental levels. Mina Hagenwall and Vikki Kanias (2006) studied the coopera- 
tion between county council and municipality when providing joint medical and social services. The respondents from both organizations admitted that the county council had a dominant position in the collaboration; they made decisions about working methods, routines and everyday duties when providing care. They planned the care before starting their collaboration with the local authorities. The municipal personnel was powerless because of the limited resources, and the short time for care provision proved to be a serious limitation and obstacle. The municipality introduced a new strategy to get a better position in the collaboration. They introduced a care-plan in line with the municipal interest, but it did not change the situation. The integration of efforts and collaboration between the municipality and the county council worked only on paper, on policy documents, but not in the everyday practice. Decentralization and the resulting regulations advocated mutual collaboration between health and social services, but actually turned into a "battle field", about power and authority, which was detrimental for the care services for seniors (SOU 2000:144). According to this study, the operative actions of county council and municipality were based on two rather different professional logics; the county council emphasized the distribution of limited resources to care providers, while the municipality was fighting for more resources for care services in order to increase the quality.

Nils Olof Hedman, Roine Johansson, and Urban Rosenqvist (2007) studied the structural integration of home care for the elderly. They identified three organizational models of home care for the elderly. The models represented the different degrees of integration based on allocated responsibility and provision for home-care services. In the first model, the county council provides medical and social services for the elderly. According to the second model, joint action is central; the county council provides medical services, while the municipality provides social services. In the third model, municipalities are responsible for medical and social services addressed to seniors. This research showed that the county councils [In Sweden it is Landsting] tended to cluster municipalities with the same organizational characteristics which caused these municipalities to follow the county council's pattern when providing care for seniors. Regarding the Edel-Reform, the intention was to give the care providers acting at the sub-national levels freedom to integrate home-care services according to their specific local circumstances. Only one percent of the Swedish municipalities have changed the organization of home-care services in relation to the county council since 1992. The research also showed that the sub-national inter-organizational networks were developed mostly according to the structures created by the county councils. The last ones took over internal control, while the municipal actors had not much to say.

Mai-Brith Schartau (1993) and, thirteen years later, Anna Dunér and Monica Nordström (2006) studied the effects of decentralization and the delegation of power to local governments. The authors argued that the scope for the acting of middle managers was not relevant for the provided resources at the local level. Middle 
managers received reduced financial resources and were expected to save money when planning and organizing care for seniors. Larsson (2008) added that politicians encouraged efficiency and financial savings without any description on how to achieve the political objectives. Also a constructive dialog between the higher authorities and care providers was lacking, which negatively influenced the public reforms of care for the elderly at the local level. Much was left to middle managers' creativity and their capacity for innovative thinking when organizing care services. Julia Pettersson-Selström (2009) argued that the Swedish managers responsible for care providing were expected to take inspiration from the private sector. Managers were burdened with administrative tasks and duties, e.g. finance, responsibility for personnel and development of operative activities. This role was steered by numerous policy documents and policy decisions about the delegations of tasks and duties. The increasing professionalism of the manager's role demanded a higher level of education to prepare them for carrying out internal controls of provided care services. Since then the care for the elderly has been perceived as a human-service organization, and it has to protect users and provide them the best service. Pettersson Selström $(2008,6)$ made a distinction between two concepts: policy objectives understood as business objectives and policy guidelines understood as the more detailed guidance for policy-making, in order to provide criteria for operational aspects, e.g. whether home-care staff ought to carry out window-cleaning or whether this service should be passed to window-cleaning companies. The guidelines should concretize and clarify the framework of activities and provide the municipal officials with the interpretation of state regulations. This study showed that the middle managers still had much discretion, at least in deciding about their own time, and how policy guidelines were implemented. However, when Pettersson Selström analyzed the same data in light of Lipsky's theory $(1980,15)$ for the street-level bureaucrats, it proved that middle managers' scope for action was rather small, and the necessary discretion to do what is needed in specific cases was absent, because their activity-planning was limited by poor budgets, extensive state regulations and political guidelines.

Decentralization was associated with the growing opportunity to make free choices of nursing homes according to the Act on the choice system in health care [Lagen om valfrihetssystem inom vård och omsorg - LOV] (SOU 2008:15) introduced on 1 January 2009; an incentive payment of 300 million was set up for a municipality that applies for resources to create the free choice conditions regarding care services to seniors. The law was intended as a voluntary tool for local governments. Jonas Frantzich Olsson and Elisabeth Martinsson (2009) studied whether the free choice system was working in practice in the Swedish municipalities. It was not working as intended. A customer could choose care services only after s/he was granted home care. The social workers were obligated to inform the client about choice alternatives; they were expected to be neutral when presenting various care offers. From this research it appeared, however, that the 
social workers were not neutral. Their understanding for neutrality varied, and clear guidelines proved necessary.

Mansour Sedaghati (2010) was also critical. The Edel-Reform emphasized the importance of free choice of nursing homes, specialized nursing home and home care services. But little was done for older people with a different cultural background and for those who did not master the Swedish language. Although there were some positive exceptions, e.g. in the Stockholm province, generally knowledge about the subjective experiences and requirements expressed by immigrants are lacking (Sedaghati 2010, 39). The older immigrants are not a homogeneous group. Therefore they have different needs. A similar problem concerns the native-born seniors who no longer understand the society of their own children. The older people, irrespective of cultural differences, want to get older with dignity and in agreement with a right to good care services, with possibilities to have additional services if needed in their specific situation, and in accordance with Swedish regulations (HSL 1982; SoL 2001:453), but the politicians have ignored the idea of individualized care.

\section{Poland}

At the beginning of the transition, the decentralization in Poland aimed at reducing the failure of central public institutions, which proved to be too formal, bureaucratic, ineffective and technical in meeting social needs. The public reforms to adapt the country to a market economy were necessary. The reforms were conducted in the spirit of NPM but it was obvious from the beginning that the central authorities did not want to lose control over the local level. The state was controlling local government through county councils and their representatives - governors [In Poland called wojewoda] (Grewiński 2006; Golinowska 2005). Stanisława Golinowska argued that the municipalities were pleased with decentralization because the delegation of tasks and duties to them created new managerial functions within the public administration at the local level, which was judged positive because of the unemployment Poland faced shortly after 1990. Golinowska distinguished two types of decentralization: Fiscal decentralization, according to which the central government transfers full responsibility for funding and organizing of social services to local governments, and administrative decentralization, which means that local governments receive funding for their activities from the central government and thereafter local authorities decide how the resources should be managed and further allocated to various service providers (Grewiński 2006, 12). According to Golinowska, in Poland the second type is dominant in public services. Private and non-government organizations have to fix their own financing for their activities. This institutional arrangement resulted in many conflicts (Gilowska 1998, 173ff.).

In conclusion, one can say that the effects of decentralizing the care for the elderly did not have the expected positive effects in Poland and Sweden. Rather, the 
result was intergovernmental conflict and a power fight to stay in control over the flow of money to local actors organizing care services for seniors. Politicians were neither sensitive to the current needs of seniors nor to service providers responsible for operative activities at the local level in either countries.

\section{d. The quality of care service}

\section{Sweden}

The Welfare Laws (SOSFS 2005:12 or 2008:10) obligated agencies delivering care service for the elderly to report any deviations. Researchers conducting empirical studies about the quality of the Swedish care services (Mold et al. 2005; Hauge and Heggen 2006; Szebehely 2006; Larsson and Shebehely 2006; Tsai and Tsai 2008; Ödegård Kjös, Botten and Romören 2008; Berggren 2010) sometimes reported occurring deviations in the care for the elderly. Reporting deviations demands systematic monitoring and documentation of all care providers, public and private ones. Staff in nursing homes is obligated to describe the degree of nursing quality, evaluate performance and take actions to improve quality according to regulations (Grimby 1998).

Szebehely (2006) shows that in 2005, $10 \%$ of all seniors received services from private care providers at home, and $13 \%$ got specialized care in nursing homes run by private actors. The quality thereof has been translated from state regulations into everyday policy, implemented at the county or municipal level. They became standards informing the number of duties which had to be performed during granted hours for the care consumer, e.g. 5 minutes for bedding, 10 minutes for a diaper change or 15 minutes for breakfast. A contract signed between purchaser and care provider has steered the scope of assistance and its quality. Good quality seems to be a very sensitive issue (Szebehely 2006, 415ff). Berggren (2010) showed that staff from nursing homes seldom reported deviations, because that was time-consuming. Reporting takes away the needed time from important care activities. According to Berggren, municipal and private care providers have reported a number of deviations and incidences per month (ca. 8-12). It seems as if h conditions required by the state regulations, but only at a minimum level. Similar to Szebehely, Berggren states that the concept of good care is unclear and demands precision.

Anna Igelström (2008) studied care consumers' subjective experiences of care services in special-care housing. She concluded that the nursing personnel should have a multitude of qualifications to satisfy the seniors' needs, e.g., emotional, social, theoretical and practical skills to create good relations with older people and to win their trust. It was most important for the seniors that the nursing personnel had social, relational, socio-pedagogic, medical and everyday practical competences. Nursing staff was expected to create and maintain good relationships with care users. Moreover, continuity in care proved very important for seniors, because it adds to the relation between care providers and care users. This research outcome has 
been confirmed by Susanne Holgersson and Malin Rööser (2008). However, when reading the Swedish official reports - SOU (2000:144; 2004:68) from two periods it shows that there are serious difficulties in recruiting staff to care for the elderly, i.e. staff with the needed skills and competences to deliver care for the elderly. The worst situation is in private services. Personnel is often recruited without the necessary skills, and they get minimum income. Both reports emphasized the same tendency. Nothing has changed in this respect.

\section{Poland,}

Agnieszka Jachowicz (2006) in her study about the nursing homes for the elderly showed that in Poland care for the elderly traditionally was based on family care. In this model, an old person was treated with respect. However, over time the role of family has changed. Young people are much more engaged in their own career development and do not have enough time to take care of their parents or grandfathers. In consequence, the older close relatives have to be placed into nursing homes. The state regulations of the 1990s and 2004 described various types of welfare homes, the range of provided services, entitlements and the way to cover necessary expenditures, but the maintenance costs of a resident within nursing homes was rather high for older people, especially single, poor people without relatives. Living in nursing homes became a luxury besides becoming a painful necessity. The reform of 2004 faced the barrier of lacking funds to cover living costs of single and poor residents. According to the Welfare Act of 2004, each municipality was expected to cover the living costs of its own residents (previously it was an obligation of the state), and to send such old people to the nearest nursing home. However, municipalities were also limited in their budgets. Local authorities were unable to increase expenditures related to the care for the elderly. It is notable that data from 2004 showed that the number of places in the nursing homes run by local governments decreased in favor of non-profit actors providing care to seniors.

Łukasz Jurek $(2009,17)$ makes an attempt of conducting a numerical analysis of nursing homes for the elderly. The results of his analysis indicate that the infrastructure of institutional care for older people is poorly developed. In 2006, there were only 15,804 places in welfare homes as opposed to 4,948,000 old persons, which means that only 3.1 places in nursing homes are available for every thousand elderly people. Regarding disabled seniors; there were 2,008,000 old disabled persons and 7.9 places in nursing homes are available for every thousand disabled elderly people. In Poland standards for the care service for the elderly were introduced. Jurek explains that the concept of standard can be understood in two ways; (1) as jointly agreed criteria, which defines common, usually the most desirable, features of something or (2) as the basic, simplest version of something. Going below standards can result in discrimination and lack of demand for such services. In the institutions providing care around the clock there are "national minimum standards" - the second variant. However, when Poles talk about standards, they 
refer to the recommendation from the EU and compare the Polish standards of care for the elderly to the standards of Western highly developed countries. The results of control in nursing-home services, conducted by NIK in 2004-2005, therefore showed many weaknesses, e.g. the presence of architectural barriers (e.g. lack of elevators, ramps, perimeter handles, railings and too narrow entrances to the bathroom and toilet), the living space per capita proved small, which limited a residents' sense of intimacy, independence and privacy, the number of bathrooms and toilets was insufficient, alarm equipment in the rooms and a fire-alarm system were lacking. Moreover, the number of staff, including employees of therapeutic-care teams proved definitely too small. Inspections carried out by the fire department and the Sanitary and Hygiene Board (SANEL) found serious failures in most homes (Jurek 2007, 19 after Informacja... 2006, 7, 20). The author analyzed the current state of institutional social care for the elderly. As the result, he presents the prospects for the development of care services and gives some pragmatic recommendations for organizing and financing the care for the elderly. His analysis is especially important in the light of the contemporary social and demographic changes resulting in an aging society. The ideas to establish a public nursing care insurance seems to be a necessary solution, even though it has drawbacks, which will be the urgent challenge for social policy in the future. Two years later, Jurek (2009) presented an empirical research about the quality of provided services based on interviews with seniors living in nursing homes. The results of this study only confirmed the previous research conducted in 2007 and the evaluations conducted by NIK in 2005.

The new control of NIK was conducted during 2007-2009 and concerned 31 municipal and communal nursing homes. The aim was to evaluate the changes in care provision after the implementation of the reform from 2004 and to control how older people were directed to nursing homes, how their stay was financed by local governments and what changed in the standard of services. It proved that strategic long-term planning, adequate for the new tasks, was still lacking. NIK was positive about the way old people were directed to nursing homes. It proved that the financing of the care for the elderly by most municipalities showed an increasing tendency for 2007-2008 from 104,607 PLZ to 141146 PLZ. Only lonely and poor seniors were directed to welfare homes. Family share in co-financing the stay in nursing homes of their elderly was 50 times lower then the expenditures of municipalities for this purpose. Local governments were not willing to pay for additional employment of social workers, even if the homes for elderly care had insufficient numbers of staff ( 1 social worker per ca. 5,000 citizens). Only 18 nursing homes for the elderly had Internet home pages, and only 5 care homes were sufficiently informative about their activities. Although expenditures on environmental care services were about seven times lower than the fees for nursing homes, the municipality efforts to develop such an environmental self-care system proved limited. Only one quarter of the municipalities extended the range of environmental care or self-help homes after 1 January 2004. This may be due to the fact that the cost of housing for envi- 
ronmental assistance, its maintenance and adjustment to current standards requires considerable efforts and funds, and the communities were not willing or not able to bear them. The standards of living in nursing homes still leave a lot to be desired (Informacja... 2010, 7ff).

Currently, the selection of a facility is very difficult for residents and their families, because of lacking information about provided care services. Jurek $(2007,21)$ argues that audit reports and other objective sources of information, talking about the actual quality level of the service at the organization, should be published and made available to everybody who has interest in them. Thus in Poland competitiveness is understood in terms of the common good, transparency and quality competition, and cooperation among various care providers. The quality of care services is of decisive importance for judging competition on a market.

In comparison to Sweden the Polish experiences are definitely worse. In Poland researchers do not report deviations and incidents. In Poland elementary standards for care providing are still lacking.

In conclusion, the NPM reforms can hardly be said to have induced a higher quality for the care users. Of course every activity is clearly monitored and described and better restricted by time limitations, but the evaluations of these changes did not improve the quality of the services. With regard to the availability of spaces in elderly homes, the lack of essential requirements thereof, the use of quality standards as minimum requirements, which often are not even met, and the unwillingness to make expenditures in the costs involved have turned a welfare service into a profit-driven business with hardly any care.

\section{Conclusions}

The purpose of this paper was to conduct a comparative research on the Swedish and the Polish care for the elderly after 1990. Two questions steered this research: What do we know about the effects of the reforms conducted in the spirit of NPM and its practical implication within the field of care for the elderly? What kind of knowledge about care for the elderly is still missing and should be developed in the future?

The Swedish and Polish empirical studies and the official reports about the public reforms conducted in the spirit of NPM were analyzed according to three theoretical perspectives of NPM movement. From the studies focusing on the first theoretical perspective - competitiveness in both countries it appears that the issue is closely related to such topics as privatization, competition and decentralization.

The Swedish and Polish studies show that the structural changes of the welfare state, including the reforms of care for the elderly, conducted in the spirit of NPM, were implemented shortly after 1990 in both countries. The policies reflected the NPM paradigm because of the tendency towards: decentralization, privatization, 
competition and free choice of public services. The Swedish Edel-Reform created the major instruments for reorganizing care for the elderly in line with Hood's understanding about improving the efficiency of the state's role in welfare provision. In Poland, outsourcing, privatization and moving welfare provision to the private market was emphasized. One of the reasons for this difference is that from the beginning of the great transformation, Poland received Western assistance to adapt the country to a market economy, which caused most reforms to occur in line with the recommendations of EU, OECD and FN, while the Swedes do not consider the EU influence on their national reforms in the field of care for the elderly. The Swedes had much more interest in implementing pilot programs and evaluating them to improve the care services at hand instead of changing its fundamental principles.

As to privatization, the number of private entrepreneurs in the care sector has been growing in both countries. In Sweden the small private companies merged into large concerns to improve their position on the market in comparison to the communal public-care deliverers. The new private care-service industry has been flourishing, but neither expected savings in municipal budget nor a high quality of care services were results. In Poland, the private care sector has developed a black market. The private companies could often develop without any permission to conduct the activities.

The quality of the Swedish care services for the elderly after the reforms has also been questioned. The objective measures of "good service" are unclear, while individual needs are ignored. It is not easy to recruit personnel to care services in general, and especially the private Swedish care providers have much less competent staff in comparison to the public care services. In Poland instead, the empirical studies focus on subjective opinions about provided care to seniors. The objective measures of good service are perceived as the basic conditions to secure the required standards of care providing according to the EU recommendations, but in practice the Polish standards do not follow the state regulations. The Swedish empirical research confirms that the authorities are working actively towards the improvement of care services for the elderly, but care providers from the private and the public sectors rarely report incidents in nursing homes. This gives the impression that care providers just want to show that they do what they are expected to do, while the quality of care is dubious. From the economic point of view, in Sweden, the care services conducted at senior's own home is the cheapest solution for the municipalities in comparison to the communal costs of nursing homes. In Poland, however, environmental care seems the cheapest. If seniors are dependent on care services, then the sector of medical care seems to be the cheapest alternative for the Polish municipalities.

Regarding the second theoretical perspective dealing with contract management, the Swedish empirical studies show that the organizational institutional context plays an important role for the reforms of care for the elderly. There are many 
stakeholders with different interests. Even if the Swedish authority regulated and specified the roles for the model of purchaser-provider, the relations between buyers and care providers are characterized by conflict and a lacking constructive dialog to improve care services according to seniors' individual needs. There is a lack of corresponding studies from Poland.

The studies dealing with the third theoretical perspective, i.e. decentralization, all argue that the municipality has a new role to play in the welfare state in both countries, but this does not come about without conflicts. The county council responsible for the allocation of resources and tasks for municipalities is still more influential than municipalities. The last one is almost powerless. The Swedish county councils [Landsting] do not want to lose power, control and influence. In Sweden the conflict between the county council and the municipal authorities is a "struggle for power" at the expense of the elderly. In Poland, such an analysis is lacking, but the Polish research on decentralization also emphasized that the delegation of power and tasks to the local level and the new division of competences resulted in many conflicts between the county council and the municipality.

Finally: What kind of knowledge about care for the elderly is still missing and should be developed in the future? This study about the reforms conducted in the spirit of NPM in Sweden and Poland within the field of care for the elderly shows what kind of knowledge is still lacking, 15-20 years after the implementation of those reforms in most European countries. In general, one can concluded that these reforms did not meet the expectations of the politicians, neither from an economic point of view nor from the perspective of higher-quality services for seniors or even free-choice alternatives on a care-market. Many weaknesses have been identified in the care for the elderly in both countries.

Regarding competition in both countries knowledge is still lacking about: 1) the expected efficiency gains in service-supply after the implementation of reforms, 2) cost-savings in public organizations, and differences in cost-saving between public and private care providers, 3) competitive threats from external actors on the market, 4) how competition among various care providers can contribute to more individualized care for older people according to their needs, and 5) staff recruitment to care services, its competencies and qualifications, but also opportunities to competence development.

Concerning contract management, neither the Swedish scholars nor the Poles studied the influence of contract management on care quality. There are no studies yet about: 1) criteria for good care services, 2) how contract management influenced the quality of care services to seniors, 3 ) how quality can and ought to be measured and improved, 4) standards for care services, 5) conflicts between politicians and local operative actors providing care services for the elderly, 6) intra-organizational relations among professional groups, gender, ethnicity and class, 7) management by objectives and to which degree goals have been achieved, 8) district reforms 
exposed to different professional logics e.g. social care and medical services, where collaborating professions have complementary values and are expected to create synergy effects to provide good care for the elderly.

In the NPM perspective on decentralization, we still know very little about: 1) what it means to have the client in focus in practice, 2) how care services can satisfy the needs of care users within various social groups, 3 ) seniors' right to autonomy in decision-making concerning themselves in nursing homes, 4) cooperation among public, non-public and commercial actors providing care for the elderly, 5) free choice of care on a market.

It seems far from rational to reform a sector, just because it is a public sector, based on a free market ideology, without having some understanding of what the effects thereof will be. Nevertheless this seems to have happened in Sweden as well as Poland, with serious side-effects, as argued in this paper.

\section{References}

Almqvist, R. 2006. New Public Management: Om konkurrensutsättning, kontrakt och kontroll. Malmö: Liber.

Andersson, G. and I. Karlberg. 2000. "Integrated Care for the Elderly: The Background and Effects of the Reform of Swedish Care of the Elderly." International Journal of Integrated Care 1, 1-10.

Andree, L. 2009. "Hembesök krävs till äldrevården" [Home visits are needed to care for the elderly]. GP, 21 September. Available at http://www.gp.se/nyheter/ halland/1.141377-hembesok-kravs-till-aldrevarden (last accessed 11 November 2011).

Balcerowicz, I. 1997. Socjalizm, kapitalizm, transformacja: Szkice $z$ przelomu epok [Socialism, capitalism, transformation: The study of the epoch-change]. Warszawa: Wydawnictwo Naukowe PWN.

Balcerowicz, I. 1995. Socialism, Capitalism, Transformation. Budapest/London/New York: Central European University Press.

Berggren, M. 2010. På SoL-sidan: Avvikelsehantering på fem vårdboenden i Uppsala kommun. Master Thesis. Institutionen för folkhälso- och vårdvetenskap. Enheten för vårdvetenskap. Uppsala universitet.

Drechsler, W. 2005. “The Rise and Demise of the New Public Management." Postautistic economics review 33, 17-28. Available at http://www.paecon.net/ PAEReview/issue33/Drechsler33.htm (last accessed 12 December 2011).

Dunér, A. and Nordström, M. 2006. "The Desire for Control: Negotiating the Arrangement of Help for Older People in Sweden." Journal of Aging Studies 24(4), 241-247. 
Dz.U. z 04-04-2004 r. Nr 64, poz. 593. Available at http://isap.sejm.gov.pl/DetailsSe rvlet?id=WDU20040640593 (last accessed 30 October 2011).

Edmark, K. 2007. Strategisk konkurrens i kommuners utgiftsbeslut för barnomsorg, skola och Äldreomsorg. Institutet för arbetsmarknadspolitisk utvärdering 21. Uppsala: IFAU.

Eurostat. 2011. Europe in Figures. Available at http://epp.eurostat.ec.europa.eu/portal/page/portal/eurostat/home (last accessed 15 March 2012).

Ferlie, E., L. E. Lynn, Jr. and Ch. Pollitt. 2005. The Oxford Handbook of Public Management. New York and London: Oxford University Press.

Frantzich Olsson, J., and E. Martinsson. 2009. I valet och kvalet: Biståndshandläggare om kundval inom äldreomsorgen. Kandidat uppsats [Bachelor essay]. Lund: Socialhögskolan, Lunds universitet.

Gerlach, Ch. and P. G. Edebalk, P. G. 2005. Organisation och marknardsorientering av äldreomsorgen: En jämförelse mellan Sverige och Tyskland. Master Thesis. Lund: Socialhögskolan, Lunds Universitet.

Gilowska, Z. 1998. "Decentralizacja systemu budżetowego jako warunek konieczny zasady subsydiarności.” In D. Milczarek (ed.). Subsydiarność. Warszawa: Centrum Europejskie UW, 173-186.

Golinowska, S. 2005. "Przyszłość państwa opiekuńczego i systemu zabezpieczenia społecznego.” Politika Spoleczna 11-12, 1-9.

Grewiński, M. 2006. "Wielosektorowa polityka społeczna - w kierunku welfare pluralism." Politika Spoleczna 5-6, 8-15.

Grimby, U. 1998. Kvalitetssystem, en handbok för hälso- och sjukvård. Göteborg: Ulla Grimby och Kaprifolen Utvecklings AB, Göteborg.

Gualmini, E. 2007. "Restructuring Weberian Bureaucracy: Comparing Managerial Reforms in Europe and the United States." Public Administration 86(1), 75-84.

GUS. 2010. Podstawowe dane o stowarzyszeniach, fundacjach i społecznych podmiotach wyznaniowych działajacych w 2008 r. Warszawa: Departament Badań Społecznych.

Hagenwall, M. and V. Kanias. 2006. Kommun och landsting: Vem har mest makt? En kvalitativ studie om den samverkan som sker mellan dessa organisationer vid vårdplanering kring äldre personer i Sverige. Kandidatuppsats. Stockholm: Institution för socialt arbetet, Stockholms universitet.

Hansson, L-E. and S. Larsson. 2011. "Vårdvalet styr resurser till dem som är friskast" [Care-choice provides resources to those who are healthy]. GP, 25 September. Available at http://www.gp.se/nyheter/debatt/1.730872-vardvaletstyr-resurser-till-dem-som-ar-friskast (last accessed 11 November 2011). 
Hauge, S. and K. Heggen. 2006. “The Nursing Home as a Home: A Field Study of Residents' Daily Life in the Common Living Rooms." Journal of Clinical Nursing, 4 April, 460-467.

Health Care Act:1992:567 [Hälso- och sjukvårdslag 1992:567]. Available at http:// www.riksdagen.se/sv/Dokument-Lagar/Lagar/Svenskforfattningssamling/ Halso--och-sjukvardslag-1982_sfs-1982-763/ (last accessed 30 October 2011).

Health Care Act 1982:763 [Hälso- och sjukvårdslag 1982:763]. Available at http:// www.notisum.se/rnp/sls/lag/19820763.htm (last accessed 1 November 2011).

Hedman, N. O., R. Johansson and U. Rosenqvist. 2007. "Clustering and Inertia: Structural Integration of Home Care in Sweden Elderly Care." International Journal of Integrated Care 7, 12. Available at http://www.ncbi.nlm.nih.gov/ pmc/articles/PMC2000976/pdf/ijic2007-200732.pdf (last accessed 30 October 2011).

Holgersson, S. and M. Rööser. 2008. När middagssällskapet lägger löständerna på bordet...: En studie av de faktorer som påverkar äldre människors upplevelser av flytt och permanent vistelse på särskilt boende eller servicehus. Kandidat uppsats [Bachelor essay]. Halmstad: Sektionen för Hälsa och Samhälle, Högskolan i Halmstad.

Hood, Christopher. 1995. "The Public Management in the 1980s: Variations on a Theme." Accounting, Organizations and Society 20(2/3), 93-109.

Hood, Christopher. 1991. “A Public Management for all Seasons?” Public Administration 69(1), 3-19.

Hrynkiewicz, J. (ed.). 2002. Przeciw ubóstwu i bezrobociu: lokalne inicjatywy obywatelskie. Warszawa: Instytut Spraw Publicznych.

HSL 1982: SoL 2001.453. Available at http://www.notisum.se/rnp/sls/lag/20010453. htm (last acessed 30 October 2011).

Igelström, A. 2008. Kompetens inom äldreomsorgen - En kvalitativ undersökning utifrån ett brukarperspektiv. Kandidat uppsats. Växjö: Institutionen för vårdvetenskap och socialt arbete, Växjö universitet.

Informacja o wynikach kontroli prawidłowości świadczenia usług przez domy pomocy społecznej (2006), Warszawa: Najwyższa Izba Kontroli [NIK].

Informacja o wynikach kontroli kierowania osób do domów pomocy spolecznej i finansowania ich pobytu przez organy samorzadu terytorialnego 2010. Warszawa: Departament Pracy, Spraw Socjalnych i Zdrowia.

Jachowicz, A. 2006. "Domy pomocy społecznej: Konieczność czy może luksus? Sytuacja DPS w świetle zmian ustawy o pomocy społecznej." Politika Spoleczna $5-6,16-20$. 
Johansson, A. 2009. "Äldrevård med många brister" [Elderly care with many shortcomings]. GP, 15 September. Available at http://www.gp.se/nyheter/ goteborg/1.90252-aldrevard-med-manga-brister (last accessed 11 November 2011).

Jurek, Ł. 2009. Zmiany stacjonarnej opieki spolecznej nad ludzmi starymi w Polsce $i$ wybranych krajach. Doctoral Thesis. Wroclaw: Uniwersytet Ekonomiczny.

Jurek, Ł. 2007. "Stacjonarna opieka spoleczna: Spojrzenie w przyszlosc." Polityka Spoleczna 5-6, 15-21.

Jurek. Ł. 2011. "The Graying World: Socio-Economical Causes and Consequences of Global Aging." In R. Borowicz, A. Karwecki, M. Nawojczyk (ed.). Culture and Education. Wyzsza Szkola Gospodarki w Bydgoszczy. Torun: Adam Marszalek, 157-172.

König, K. 1997. "Entrepreneurial Management or Executive Administration: The Perspective of Classical Public Administration." In W. M.J. Kickert (ed.). Public Management and Administrative Reform in Western Europe. Cheltenham: Edward Elgar, 213-232.

Larsson, K. 2008. Mellanchefer som utvecklar. Linköping: Institutionen för beteendevetenskap och lärande.

Larsson, K. and M. Szebehely. 2006. "Kapitel 16: Äldreomsorgens förändringar under de senaste decenierna." Available at http://www.scb.se/statistik/_publikationer/le0101_1980i05_br_17_le112sa0601.pdf (last accessed 5 November 2011).

Leś, E. 2000. Od filantropii do pomocniczości: studium porównawcze rozwoju i działalności organizacji społecznych. Warszawa: Prószyński i S - ka.

Lipsky, M. 1980. Street Level Bureaucracy. New York: Russell Sage Foundation.

Manning, N. 2001. "The Legacy of the New Public Management in Developing Countries." International Review of Administrative Sciences 67(2), 297-312.

Mold, F., J. M. Fitzpatrick and J. D. Roberts. 2005. "Minority Ethnic Elders in Care Homes: A Review of the Literature." Age and Ageing, 11 January, 107-113.

Montin, S. 1997. "New Public Management på svenska." Politica 29(3), 261-278.

National Welfare Board. 2003. Socialstyrelsen. Available at http://www.socialstyrelsen.se/ (last accessed 30 October 2011).

Nemec, J. 2010. "New Public Management and its Implementation in CEE: What Do we Know and where Do we Go?" NISPAcee Journal of Public Administration and Policy 3(1), 33-56.

NIK. 2011. Sprawozdanie z dzialanosci Najwyzszej Izby Kontroli w 2010 roku. Warszawa: NIK. 
Osborne, D. and T. Gaebler. 1992. Reinventing Government. Reading, Mass: Addison Wesley.

Pettersson-Selström, J. 2008. Handlingsutrymmets förutsättningar och konsekvenser - En studie om mellanchefer $i$ kommunal omsorg. Kandidatuppsats. Växjö: Institutionen för vårdvetenskap och socialt arbete, Växsjö universitet.

Pierre, J. 1993. "Legitimacy, Institutional Change, and the Politics of Public Administration in Sweden." International Political Science Review 14(4), 387-401.

Pollitt, C. and G. Bouckaert. 2004. Public Management Reform. A Comparative Analysis, Oxford: Oxford University Press.

Pollitt, C and S. Dan. 2011. "The Impacts of the New Public Management in Europe: A Meta-Analysis." Paper submitted for the EGPA permanent study group II - Performance in the public sector, 7-10 September 2011, Bucharest. Available at http://egpa-conference2011.org/documents/PSG2/POLLITT-DAN. pdf (last accessed 16 October 2011).

Rymsza M. 2003. "Kontraktowanie zadań publicznych jako forma współdziałania państwa i organizacji non-profit." In B. Rysz-Kowalczyk and B. Szatur-Jaworska (eds). Wokót teorii polityki społecznej, Warszawa: Instytut Polityki Spolecznej UW, 261-277.

Schartau, M.-B. 1993. The Public Sector Middle Manager: The Puppet who Pulls the Strings? Lund: Lunds Universitet.

Sedaghati, M. 2010. Elder Migrants and the Public Elderly Care: A Literature Review. Kandidat uppsats. Stockholm: Institutionen för social arbete, Stockholms universitet.

Sobis, I. 2002. Employment Service in Transition: Adaptation of a Socialist Employment Agency to a Market Economy. A Case Study of Lodz, Poland 1989-1998. Doctoral Thesis. Gothenburg Studies in Sociology No 11, Department of Sociology. Gothenburg: Gothenburg University.

Sobis, I. and M. S. de Vries. 2009. The Story behind Western Advice to Central Europe during its Transition Period. Bratislava: NISPAcee Press.

SOSFS 2005:12. Available at http://www.sls.se/Global/cpd/SOSFS\%202005_12.pdf (last accessed 19 November 2011).

SOSFS 2008:10. Available at http://www.socialstyrelsen.se/sosfs/2008-10/2008-10 (last accessed 19 November 2011).

SOU 2008:15. LOV att välja - Lag Om Valfrihetssystem. Available at http://www. regeringen.se/sb/d/10057/a/99454 (last accessed 5 November 2011).

SOU 2001:79. Välfärdsbokslut för 1990-talet. Available at http://www.regeringen. $\mathrm{se} / \mathrm{sb} / \mathrm{d} / 186 / \mathrm{a} / 2752 /$ dictionary/true (last accessed 5 November 2011). 
SOU 2000:144. Samverkan - om gemensamma nämnd på vård och omsorgområdet. Available at http://www.regeringen.se/sb/d/108/a/2819 (last accessed 5 November 2011).

SOU 2004:68. Vård och omsorg - faktabakgrund. Available at http://www.regeringen.se/content/1/c6/02/65/84/ce9c18bf.pdf (last accessed 5 November 2011).

Starzman, K. 2011. "Vårdvalet är underfinansierat" [Choice of Health Care is under-founded]. GP, 25 September. Available at http://www.gp.se/nyheter/ debatt/1.730863-vardvalet-ar-underfinansierat (last accessed 20 November 2011).

Stolt, R. and P. Jansson. 2006. Den privata äldreomsorgsmarknaden: etablering, utveckling och konkurrens. Kandidatuppsats. Företagsekonomiska institutionen. Stockholm universitet.

Stolt, R., and U. Winblad. 2009. "Mechanisms behind Privatization: A Case Study of Private Growth in Swedish Elderly Care." Social Science \& Medicine 68(5), 903-911.

Supińska, J. 2003. "Podmioty polityki społecznej: współistnienie, współpraca, współzawodnictwo,", In B. Rysz-Kowalczyk and B. Szatur-Jaworska (eds). Wokót teorii polityki społecznej, Warszawa: Warszawa: Instytut Polityki Spolecznej UW. Available at http://www.ips.uw.edu.pl/cat_view/40-plikipracownikow-ips/46-prof-jolanta-supiska.html (last accessed 15 November 2011).

Svensson, M. and P. G. Edebalk. 2006. Kvalitetskonkurrens och kundval inom kommunal äldreomsorg. Stockholm: Konkurrensverkets uppdragsforskningsserie.

Szebehely, M. 2006. "Omsorgsvardag under skiftande organisatoriska villkor: en jämförande studie av den nordiska hemtjänsten." Tidskrift for Arbejdsliv 8(1), $49-66$.

Thompson, J. 1969. Hur organisationer fungerar. Stockholm: Prisma.

Tsai, H.-H. and Y.-F. Tsai. 2008. "A Temporary Home to Nurture Health: Lived Experiences of Older Nursing Home Residents in Taiwan." Journal of Clinical Nursing, 19 July, 1915-1922.

Vries, M. de and J. Nemec. 2012. "Public Sector Reform: Which Way Are we Headed? An Overview of Recent Literature and Research." International Journal of Public Sector Management, forthcoming. 
Welfare Act of 12 March 2004. [Dziennik Ustaw Rzeczypospolitej. Ustawa o pomocy spolecznej z 12 marca 2004 Warszawa: Dz. U. z 15 kwietnia 2004 r., Nr 64. poz. 593, ze zm.) (Warsaw: Statute Books. No. 64, position 593]. Available at http://www.mpips.gov.pl/gfx/mpips/userfiles/File/Wsparcie\%20dla\%20 rodzin $\% 20 z \% 20 \mathrm{dziecmi} /$ adopcja/ustawa_o_pomocy_spolecznej.pdf (last accessed 1 March 2012).

Welfare Act 2001:453. Available at http://www.riksdagen.se/sv/Dokument-Lagar/ Lagar/Svenskforfattningssamling/Socialtjanstlag-2001453_sfs-2001-453/ (last accessed 1 November 2011).

Welfare Act 1997:313. Available at http://www.notisum.se/rnp/sls/lag/19800620.htm\#P20_a http://www.riksdagen.se/webbnav/index.aspx?nid=3911\&bet=1980:620 (last accessed 1 November 2011).

Welfare Act 1993:390. [Socialtjänstlag 1993:390] (November 1, 2011). Available at http://www.notisum.se/rnp/sls/fakta/a9800620.htm (last accessed 1 March 2012).

Welfare Act of 29 November 1990. [Dziennik Ustaw Rzeczypospolitej 2004. Ustawa o pomocy spolecznej z 29 listopada 1990 Warszawa: Dziennik Ustaw, No. 64, poz. 593. (Warsaw: Statute Books. No. 64, position 594. Available at http:// www.google.se/search?q=Ustawa+o+pomocy+spolecznej+1990\&ie=utf$8 \&$ oe $=$ utf- $8 \&$ aq=t\&rls=org.mozilla:sv-SE:official\&client=firefox-a (last accessed 1 March 2012).

Welfare Act 1980:620. [Socialtjänstlagen 1980:620; 1993:390]. Available at http:// www.riksdagen.se/webbnav/index.aspx?nid=3911\&bet=1980:620 (last accessed 30 October 2011).

Welfare Act 1980:629. [Socialtjänstlagen 1980:629]. Available at http://www.riksdagen.se/sv/Start/Sok/?sok=Socialtj\%c3\%a4nstlagen+1980:629\&searchtype=al $1 \&$ facets $=1 \& a=s \&$ sortorder $=$ desc\&sort $=$ rel (last accessed 30 October 2011).

Wilhelmsson, T. and H. Jordahl. 2010. Privat drift av offentligt finansierad äldreomsorg: Vilka är effekterna på kostnad och kvalitet? Kandidatuppsats. Uppsala: Nationalekonomiska institutionen, Uppsala universitet.

Äldreomsorg och hälso- och sjukvård under 90-talet: Utveckling, omprövning, prioritering. 2003. Stockholm: Svenska Kommunförbundet och Landstingsförbundet.

Ödegård Kjös, B., G. Botten and T.-I. Romören. 2008. "Quality Improvement in a Publicly Provided Long-Term Care System: The Case of Norway." International Journal for Quality in Health Care, 30 June, 433-438.

Österström, S. 2007. Om konsten att överbygga gränser. En fallstudie om kommunal äldreomsorg och samspelet med andra organisationer. Linköping: Institutionen för beteendevetenskap och lärande, Linköpings universitet. 